\title{
Pengaruh Peringatan Bahaya Rokok Bergambar pada Intensi Berhenti Merokok
}

\author{
STEPHANI RAIHANA HAMDAN \\ Fakultas Psikologi, Universitas Islam Bandung, Jl. Tamansari No.1 Bandung 40116 \\ email : stephanie.raihana@gmail.com
}

\begin{abstract}
Smoking is a very common addictive behavior in Indonesia. The efforts to restrict smoking behavior always met difficulties. The latest government effort is change the warning hazard of the smoking behavior with pictorial warning. This policy is conducted since 2014 in order to raise awareness of smoking cessation. The goals of this study is to measure the effects of smoking pictorial warnings on intentions to quit smoking. The subject of this study is a beginner smoker. The study was conducted with an experimental research design using factorial design. The results show a warning picture with smokingrelated diseases place by the caption brief warning is more effective to increase intentions to quit smoke. It is expected of the government to implement this study results as the first step in improving the people's desire to quit smoking.
\end{abstract}

Keyword: Cigarette, Intention, Pictorial Warning Hazard, Smoking.

\begin{abstract}
Abstrak. Perilaku merokok telah menjadi perilaku adiktif yang umum ditemui di Indonesia. Upaya pembatasan perilaku merokok sulit dilakukan. Perubahan peringatan bahaya rokok bergambar diterapkan sejak 2014 dalam rangka menumbuhkan kesadaran berhenti merokok. Penelitian ini bertujuan mengukur pengaruh peringatan bahaya rokok bergambar terhadap intensi berhenti merokok pada subjek perokok pemula. Penelitian dilakukan dengan desain penelitian eksperimental menggunakan rancangan Factorial Design. Hasil penelitian menunjukkan peringatan dengan gambar penyakit akibat rokok disertai tulisan peringatan yang singkat lebih efektif berpengaruh dibandingkan gambar dan tulisan peringatan yang lain. Diharapkan pemerintah dapat menerapkan jenis peringatan bahaya rokok yang lebih terbukti lebih berpengaruh sebagai langkah awal dalam meningkatkan keinginan masyarakat untuk berhenti merokok.
\end{abstract}

Kata kunci: Gambar, Intensi, Merokok, Peringatan Bahaya Rokok.

\section{Pendahuluan}

Perilaku merokok telah menjadi perilaku adiktif yang umum ditemui di Indonesia. Perilaku merokok merupakan tindakan seseorang melakukan kegiatan merokok atau tindakan-tindakan yang dilakukan secara sengaja untuk merangsang untuk merokok, serta hasil keputusan seseorang setelah mempertimbangkan buruk baiknya merokok. Informasi mengenai rokok dari lingkungan merupakan hal penting yang mempengaruhi pertimbangan baik tidaknya rokok. Oleh karen itu proses pengambilan keputusan untuk merokok sangat dipengaruhi oleh lingkungan. (Efendi, 2005: 17)

Menurut Laventhal dan Clearly, terdapat empat tahap dalam merokok, yaitu tahap persiapan (preparatory), tahap perintisan (initiation), tahap menjadi perokok (becoming a smoker) dan tahap perokok tetap (maintaining of smoking). Dalam tahap persiapan, seseorang tertarik dan berniat untuk merokok, sedangkan dalam tahap perintisan seseorang mencoba dan memutuskan untuk meneruskan atau berhenti merokok, pada tahap perokok, seseorang telah mengkonsumsi secara lebih teratur hingga 4 batang perhari sedangkan pada tahap perokok tetap, seseorang telah kecanduan efek menyenangkan rokok dan tidak bisa berhenti. (Aula, 2010: 36)

Rokok bila dikonsumsi dapat menjadi sumber berbagai masalah kesehatan seperti kanker, jantung, gangguan pernafasan serta

Received: 21 Februari 2015, Revision: 25 Mei 2015, Accepted: 4 Juni 2015

Print ISSN: 0215-8175; Online ISSN: 2303-2499. Copyright@2015. Published by Pusat Penerbitan Universitas (P2U) LPPM Unisba Terakreditasi SK Kemendikbud, No.040/P/2014, berlaku 18-02-2014 s.d 18-02-2019 
menjadi salah satu penyumbang kematian terbesar. Tingkat kematian akibat merokok di Indonesia telah mencapai 57.000 orang per tahun. (Aula, 2010: 12) Merokok ternyata tidak hanya menimbulkan sejumlah bahaya medis yang mematikan, namun rokok juga memiliki bahaya psikologis, misalnya depresi dan skizofrenia. Kecanduan merokok juga merupakan bentuk perilaku adiktif yang menjadi masalah kesehatan jiwa sehingga dikelompokkan pada gangguan kecanduan. (Albery \& Mufano, 2011: 101).

Namun demikian, konsumsi rokok tetap tinggi dan menjadi masalah adiktif yang sulit diputus mata rantainya. Saat ini Indonesia menjadi urutan negara tertinggi di Asia Tenggara yang memiliki perokok tetap terbanyak. Diperkirakan 225 milliar batang rokok dihabiskan penduduk Indonesia per tahunnya. Jumlah penduduk Indonesia yang merokok hampir mencapai 61,4 juta penduduk. (Nurcahyani dalam www.okezone. com).

Indonesia saat ini merupakan "surga" bagi para perokok dengan pertumbuhan konsumsi rokok terpesat di dunia. Survey Global Adult Tobacco Survey (GATS) Indonesia tahun 2011 menunjukkan, Indonesia menduduki posisi pertama dengan prevalensi perokok aktif tertinggi diantara 16 negara berkembang lain yang disurvey. (Kementerian Kesehatan RI dalam depkes.go.id) Perokok aktif laki-laki di Indonesia mencapai 67 persen. Tingginya perokok aktif laki-laki tersebut akan memengaruhi kesehatan perempuan dan anak yang terpapar asap rokok laki-laki yang merokok di rumah atau di tempat publik. Di Indonesia, angka prevalensi merokok tergolong tinggi di kalangan pria. Pada 2012, sebanyak 57\% pria Indonesia digolongkan sebagai perokok aktif dan tercatat sebagai kedua tertinggi di dunia. (Candra dalam health.kompas.com)

Kendala utama pembatasan merokok di Indonesia, tidak lain dikarenakan faktor ekonomi. Rokok dianggap sebagai barang menguntungkan. Departemen Perindustrian menyebutkan bahwa pemerintah menargetkan peningkatan produksi rokok menjadi 260 miliar batang pada tahun 2015-2020. Hal ini dilakukan karena pemerintah mendapat untung sebesar 57 trilyun rupiah setahun dari cukai rokok. Tak heran bila pemerintah RI menjadi satu-satunya negara di Asia yang tidak mau meratifikasi Framework Convention on Tobacco Control (Sarah, 2008 : 38 dan Tim KPAI dalam www.kpai.go.id).
Konsumsi rokok tahun 2008 mencapai 240 miliar batang per hari atau 658 juta batang per hari. Ini berarti 330 Miliar Rupiah "dibakar" oleh perokok Indonesia dalam sehari Padahal konsumsi terbesar rokok yaitu $60 \%$ dari total perokok aktif di Indonesia adalah masyarakat ekonomi menengah ke bawah (miskin). Sehingga disatu sisi pemerintah diuntungkan melalui cukai rokok dan mengorbankan kesehatan masyarakat miskinnya. Pembatasan rokok melalui Framework Convention on Tobacco Control akan secara langsung membatasi konsumsi rokok dan secara logis menurunkan tingkat kecanduan. (kompas.com, 2012)

Lebih miris lagi saat melihat data Survei Sosial Ekonomi Nasional (Susenas) yang menunjukkan bahwa masyarakat miskin lebih memilih mengonsumsi rokok daripada komoditas konsumsi yang lain. Hal ini belum termasuk konsumsi yang berkaitan dengan rokok, misal korek api. Data Susenas (2006) menunjukkan masyarakat miskin mengkonsumsi rokok 17 kali lebih banyak daripada daging, 15 kali daripada investasi kesehatan (multivitamin, jamu, dsb), 9 kali lebih memilih membeli rokok dibandingkan membiayai pendidikan (sekolah, kursus, les, membeli buku, dsb) serta 5 kali lebih banyak memilih rokok daripada susu dan telur. Survei tersebut juga menyatakan bahwa 1 dari 2 rumah miskin mengalokasikan pendapatannya untuk membeli rokok. Ratarata pengeluaran rokok masyarakat miskin perbulan mencapai Rp. 120.000. Para perokok dari golongan miskin ini membelanjakan uangnya untuk rokok 2,5 kali lipat lebih besar daripada pengeluaran biaya untuk pendidikan. Tak heran pembangunan di Indonesia berjalan lambat, karena penduduknya lebih mementingkan rokok dibandingkan sekolah (Aula, 2010: 29).

Salah satu alasan rokok menjadi komoditas yang laris di pasar Indonesia antara lain harga rokok yang murah dan terjangkau. Selain itu, aturan pembatasan peredaran dan konsumsi rokok di Indonesia yang masih cenderung longgar dan tidak terawasi dengan baik sehingga memudahkan akses bagi perokok. Terdapat beberapa aturan terkait konsumsi rokok di Indonesia yaitu PP No.19 Tahun 2003 tentang Pengamanan Rokok Bagi Kesehatan yang mencakup kandungan rokok, syarat penjualan rokok, syarat iklan dan promosi serta kawasan tanpa rokok. Di kota Bandung sendiri, terdapat aturan Perda Kota Bandung No. 11 Tahun 2005 Pasal 23 yang mengatur bahwa tempat 
umum, sarana kesehatan, tempat kerja, dan tempat yang secara spesifik sebagai tempat proses belajar mengajar, arena kegiatan anak, tempat ibadah dan angkutan umum dinyatakan sebagai kawasan tanpa merokok. Namun nyatanya rokok masih dengan mudah di temui di berbagai tempat yang harusnya bebas rokok. (kompas.com, 2013 dan bppt. jabarprov.go.id)

Bila di evaluasi pelaksanaan aturanaturan ini tidak menghentikan daya tarik rokok. Menteri Kesehatan Endang Rahayu Sedyaningsih juga menyatakan iklan dan promosi rokok di media massa yang dikemas sangat bagus menjadi salah satu daya tarik masyarakat Indonesia untuk merokok. (depkes.go.id) Oleh karena itu disusun Permenkes No 28 Tahun 2013 yang akan membatasi iklan, promosi, dan sponsorship rokok (sindotrijaya.com dan Sulaiman dalam detik.com).

Dalam hal memasarkannya perusahaan rokok melakukan berbagai cara untuk menarik minat perokok untuk mengkonsumsi rokok yang dijualnya. Mulai dengan iklan menggunakan media televisi, penggunaan billboard, menggunakan bungkus rokok yang menarik bagi perokok dan lain sebagainya. Di Indonesia saja masih banyak iklan rokok yang ditampilkan di televisi tanpa ada batasan jam pemunculan iklan tersebut. Sehingga aturan Permenkes dinilai mandul dalam membatasi iklan rokok. Sejak 24 Juni 2014 telah diterapkan pula peringatan bahaya rokok yang baru yang memiliki gambar. Aturan penempelan gambar bahaya merokok itu tertuang dalam Peraturan Pemerintah No 109/2012. Kementerian Kesehatan (Kemenkes) sudah menyosialisasikan lima gambar yang dipasang di bagian "kepala" bungkus rokok. (kompas.com) Oleh karena itulah penelitian ini bertujuan untuk mengetahui pengaruh peringatan bahaya rokok bergambar yang kini diterapkan oleh pemerintah terhadap intensi berhenti merokok.

\section{Peringatan Bahaya Merokok}

Dilakukan penelitian dengan cara mengukur pengaruh pemberian peringatan bahaya rokok bergambar bagi perubahan intensi berhenti merokok. Pengukuran dilakukan menggunakan metode Experimental dengan rancangan Factorial Design $4 \times 2$. Hal ini dilakukan dengan cara membandingkan antara gambar peringatan penyakit dan gambar bahaya asap rokok beserta tulisan peringatan bahaya rokok.

Berdasarkan Peraturan Pemerintah No 109/2012. Kementerian Kesehatan (Kemenkes) sudah menyosialisasikan lima gambar peringatan bergambar baru. Lima gambar itu adalah kanker mulut, kanker paruparu dan bronkitis akut, kanker tenggorokan, merokok membahayakan anak (ilustrasi bapak menggendong anak sambil merokok). Kementerian Kesehatan memutuskan lima gambar itu sebagai visualisasi bahaya merokok yang telah melalui survei Fakultas Kesehatan Masyarakat (FKM) Universitas Indonesia (UI). Di Indonesia, ukuran gambar peringatan itu ditetapkan 40 persen dari total luas bungkus rokok. Jika ada perusahaan rokok yang tidak mencantumkan gambar itu, sanksinya berupa hukuman pidana 5 tahun dan denda Rp 500 juta. (www.jawapos.com)

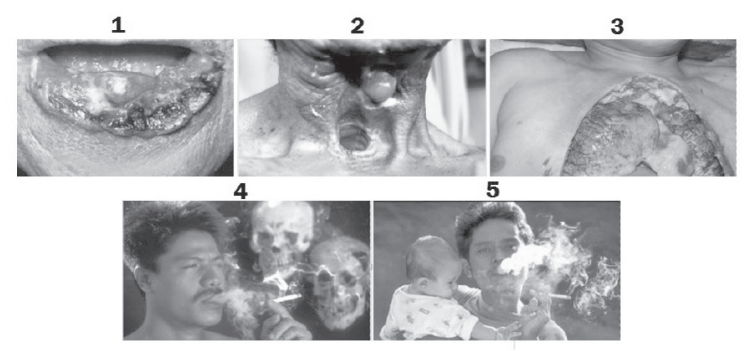

Gambar 1. peringatan bahaya rokok tahun 2014

Gambar 1, 2, dan 3 merupakan gambar peringatan penyakit akibat merokok dan gambar 4, 5 merupakan gambar peringatan bahaya asap rokok. Tulisan peringatan bahaya rokok juga dibuat lebih singkat. Kalimat peringatan lama bertuliskan "MEROKOK DAPAT MENYEBABKAN KANKER, SERANGAN JANTUNG, IMPOTENSI DAN GANGGUAN KEHAMILAN DAN JANIN".

Kalimat lama yang panjang kini diganti dengan kalimat terbaru yang terdapat pada setiap iklan dan bungkus rokok saat ini adalah kalimat yang lebih singkat dan to the point, yaitu "MEROKOK MEMBUNUHMU".

Oleh karena itu, dalam penelitian ini variabel yang akan diteliti adalah pengaruh variabel independen terhadap variabel dependen. (Hatta, 2013 : 57) Dalam penelitian ini variabel independen adalah pemberian peringatan bahaya rokok bergambar dengan variabel dependen penelitian yaitu intensi berhenti merokok.

\section{Tabel 1}

Penelitian Eksperimen Factorial

\begin{tabular}{|l|l|}
\hline A1 & A2 \\
\hline A1B1 & A2B1 \\
\hline
\end{tabular}




\begin{tabular}{|l|l|}
\hline A1B2 & A2B2 \\
\hline
\end{tabular}

A1 : Tulisan Peringatan Lama

A2 : Tulisan Peringatan Baru

B1 : Gambar penyakit

B2 : Gambar bahaya asap rokok

Dalam penelitian ini pemberian peringatan bahaya rokok bergambar yaitu pemberian visualisasi peringatan bahaya penyakit yaitu kanker mulut, kanker parubronkitis akut-tenggorokan serta pemberian visualisasi peringatan bahaya asap rokok yaitu merokok membahayakan anak (ilustrasi bapak menggendong anak sambil merokok) dan merokok dapat membuat kematian (ilustrasi orang merokok disamping tengkorak). Peringatan bahaya merokok adalah pemasangan iklan dengan disertai gambar penyakit menyeramkan dan tulisan peringatan yang bernada keras yang bertujuan untuk mencegah anak dibawah umur dan perokok pemula agar tidak mengkonsumsi dan berhenti merokok.

Untuk intensi berhenti merokok mengacu pada teori Ajzen (2005: 25) yang menyatakan bahwa intensi adalah suatu indikasi kesiapan seseorang untuk menampilkan suatu tingkah laku. Semua perilaku termasuk perilaku merokok, diawali oleh adanya intensi. Seseorang mulai merokok bila memiliki niat (intensi) untuk merokok. Menurut Ajzen (2005 : 54) intensi dipengaruhi oleh tiga faktor dasar perilaku. Pertama, sikap terhadap perilaku (attitude toward the behavior) yaitu sikap seseorang terhadap realisasi perilaku dalam situasi tertentu. Kedua, norma subyektif (subjective norm) yang merupakan norma-norma sosial yang mempengaruhi dan dianut individu. Ketiga, persepsi terhadap kendali perilaku (perceived behavior control) yaitu keyakinan seseorang akan kemampuannya melakukan suatu perilaku. Sehubungan dengan intensi mencoba merokok ketiga faktor tersebut ikut mempengaruhi.

Sikap terhadap perilaku mengacu pada penilaian individu bahwa perilaku yang akan dilakukan itu baik atau buruk, bahwa individu suka atau tidak suka menjalankan perilaku itu. Norma subjektif mengacu pada persepsi individu terhadap tekanan sosial yang mengharuskan atau melarangnya untuk menjalankan perilaku itu. Persepsi atas kendali perilaku mengacu pada keyakinan individu bahwa ia mampu atau tidak mampu menjalankan perilaku tertentu. Intensi dikatakan kuat dan berpotensi untuk diwujudkan dalam perilaku, jika individu menilai bahwa perilaku itu baik/suka untuk dilakukan, bahwa ia harus melakukan perilaku itu, dan bahwa ia merasa mampu untuk mewujudkan perilaku itu.

Hal ini juga berlaku dalam perilaku merokok. Bila seseorang merasa rokok sebagai suatu yang wajar dan menyenangkan, merasa harus mencoba rokok atas tekanan lingkungan dan merasa mampu merokok, intensi seseorang untuk merokok kuat dan kemungkinan seseorang akan merokok tinggi. Sikap yang positif terhadap rokok, nilai-nilai sosial yang mengajak merokok serta adanya keyakinan bahwa rokok tidak merugikan dan mampu ia lakukan, keseluruhannya membentuk intensi perilaku merokok. (Mubarak, 2014: 37-40)

Jalannya eksperimen pertama kali dilakukan adalah pemilihan sampel dari populasi yang ada 40 perokok pemula di kota Bandung secara acak atau random. Setelah itu akan dibagi menjadi 4 kelompok yang masing-masing akan mendapatkan treatment yang berbeda dan masing-masing subjek dari setiap kelompok akan diberikan angket yang harus diisi mengenai intensi mereka untuk berhenti merokok dari bahaya rokok yang sudah dilihatnya.

Treatment berupa gambar peringatan bahaya rokok. Visualisasi gambar adalah gambar bentuk yang dapat menjelaskan hal-hal secara visual yang dapat dijadikan sebagai alat untuk mengkomunikasikan informasi selain menggunakan tulisan. Dalam berbagai bidang, visualisasi digunakan untuk mempermudah mengkomunikasikan suatu pesan atau informasi agar lebih mudah untuk dipersepsikan oleh seseorang. Visualisasi yang dipakai dalam eksperimen ini adalah gambar penyakit yang disebabkan oleh rokok dan tulisan yang sesuai dengan pesan bahaya dari perilaku merokok. Sehingga subjek akan lebih mempersepsikan bahwa bahaya merokok adalah hal yang nyata.

Roland Barthes (1915-1980) dalam Rustan (2009: 27), seorang kritikus literature dan sosial Perancis menulis dalam essay-nya tahun 1964 berjudul 'Rhetoric of the image' sebagai berikut: "karena gambar (image) bersifat polisemy (mengandung banyak makna yang berbeda), maka teks digunakan untuk member gambar itu makna sebenarnya yang dimaksudkan." Menurut Barthes, tulisan lebih mendominasi. Buktinya buku-buku cerita maupun dokumentasi yang hanya 
berisi teks tanpa gambar dapat survive dari dulu hingga sekarang (jauh lebih banyak pula jumlahnya dibandingkan buku bergambar tanpa teks yang jumlahnya hanya berapa gelintir saja). Di lain pihak, manusia berfikir secara visual (dengan gambar bukan tulisan) dan dalam beberapa kasus, menyampaikan pesan dengan gambar dapat lebih efektif dibanding tulisan.

Alasan mengapa peringatan merokok lebih baik berupa gambar dibanding tulisan adalah karena pesan kesehatan pada bungkus rokok langsung menyampaikan informasi penting kepada perokok. Pesan peringatan akan senantiasa diulang dan direinforced setiap seseorang merokok. Para perokok lebih mempercayai dan mengingat pesan dibanding jika diberikan kampanye pendidikan bahaya rokok. Harga cenderung lebih rendah untuk diimplemetasikan oleh pemerintah dan yang membayar biaya cetaknya adalah perusahaan rokok. Syarat-syarat membuat gambar peringatan yang efektif adalah gambar dan tulisan harus jelas dan sederhana. Peringatan dikombinasikan dengan sesuatu yang akan membuat para perokok semakin yakin untuk berhenti dan peringatan dapat mengingatkan.

Alasan pesan peringatan dapat membantu para perokok untuk berhenti adalah karena dapat membantu para perokok memahami bahwa penyakit yang disebabkan oleh rokok adalah serius dan seberapa besar kemungkinan mereka dapat terkena penyakit tersebut. Peringatan bahaya rokok di bungkus rokok juga dapat menghubungkan peringatan dengan pengalaman mereka jadi pesannya akan lebih diterima dan dipercaya serta dapat memotivasi mereka untuk mengambil langkah dalam memelihara kesehatan.

Perokok akan menyadari dan memikirkan informasi mengenai bahaya rokok apabila peringatan berada di atas dan di depan bungkus rokok, dimana peringatan yang dilihatnya spesifik dan jelas dengan penjelasan mendalam (bukan umum seperti "merokok itu berbahaya). Sebaiknya peringatan tersebut juga membangkitkan respon emosi karena sangat nyata dan jelas. Peringatan juga perlu diubah secara berkala dan ketika peringatan sudah mulai diabaikan. (www.smoke-free.ca/warnings/)

Alat ukur yang digunakan dalam penelitian ini adalah angket. Pengukuran intensi dilakukan dengan cara menanyakan derajat kesesuaian (sesuai-tidak sesuai) atau kesetujuan (setuju-tidak setuju) yang dimiliki subjek terhadap pernyataan yang diajukan. derajat kesesuaian/kesetujuan tersebut menggunakan skala $5(-2 \mathrm{~s} / \mathrm{d}+2)$ ataupun 7 $(-3 \mathrm{~s} / \mathrm{d}+3)$. Dalam penelitian ini tes dilakukan satu kali yaitu postest. Pengontrolan validitas dilakukan pada Tabel 2 .

Tabel 2

\section{Controlled Variables}

\begin{tabular}{|c|c|c|c|}
\hline & APA & Bagaimana & Mengapa \\
\hline \multirow[t]{6}{*}{ SUBJEK } & Jenis Kelamin & $\begin{array}{l}\text { Peneliti memilih subjek laki- } \\
\text { laki. }\end{array}$ & $\begin{array}{l}\text { Penelitian membuktikan bahwa } 67 \% \text { perokok } \\
\text { aktif berjenis kelamin laki-laki. }\end{array}$ \\
\hline & Umur & $\begin{array}{l}\text { Peneliti memilih subjek berusia } \\
18 \text { tahun keatas }\end{array}$ & $\begin{array}{l}\text { Karena penelitian membuktikan bahwa batas } \\
\text { legal usia untuk merokok adalah } 18 \text { tahun } \\
\text { keatas. }\end{array}$ \\
\hline & Tingkat adiksi & $\begin{array}{l}\text { Peneliti memilih perokok } \\
\text { pemula (tingkat ringan } \\
\text { merokok } 1-10 \text { batang sehari) }\end{array}$ & $\begin{array}{l}\text { Karena, peneliti ingin mencoba apakah ada } \\
\text { pengaruh dari visualisasi peringatan bahaya } \\
\text { merokok terhadap perokok pemula }\end{array}$ \\
\hline & Fisiologi & $\begin{array}{l}\text { Peneliti memilih subjek tidak } \\
\text { pernah mengalami kecelakaan } \\
\text { berat yang mengakibatkan } \\
\text { cedera otak, waktu tidur cukup } \\
\text { dan telah sarapan. }\end{array}$ & $\begin{array}{l}\text { Karena cedera otak dan kondisi fisik yang } \\
\text { tidak optimal akan mempengaruhi penilaian } \\
\text { seseorang dalam situasi sehari-hari. }\end{array}$ \\
\hline & Pendidikan & Mahasiswa S1 & $\begin{array}{l}\text { Faktor pendidikan berkaitan dengan wawasan } \\
\text { dan pemahaman seseorang. }\end{array}$ \\
\hline & Emosi & $\begin{array}{l}\text { Peneliti memastikan subjek } \\
\text { memiliki waktu tidur yang } \\
\text { cukup, tidak stress, dan subjek } \\
\text { telah sarapan. }\end{array}$ & $\begin{array}{l}\text { Karena keadaan emosi mempengaruhi } \\
\text { penilaian seseorang terhadap suatu stimulus. }\end{array}$ \\
\hline GAMBAR & Ukuran & $\begin{array}{l}\text { Peneliti memilih gambar } \\
\text { dengan ukuran banner } 90 \mathrm{~cm} x \\
60 \mathrm{~cm}\end{array}$ & $\begin{array}{l}\text { Karena semakin besar gambar akan } \\
\text { mempengaruhi daya tarik seseorang dan setiap } \\
\text { subjek mendapatkan stimulus visualisasi } \\
\text { dengan ukuran yang sama. }\end{array}$ \\
\hline
\end{tabular}




\begin{tabular}{|c|c|c|c|}
\hline & Warna & $\begin{array}{l}\text { Peneliti memilih warna yang } \\
\text { sesuai dengan gambar yang } \\
\text { akan digunakan yaitu abu } \\
\text { hitam putih dan merah }\end{array}$ & $\begin{array}{l}\text { Karena warna mempunyai makna tertentu } \\
\text { yang memiliki arti yang negatif, dan agar } \\
\text { semua subjek mendapatkan stimulus yang } \\
\text { sama. }\end{array}$ \\
\hline & Pixel/Size & $\begin{array}{l}\text { Peneliti memilih gambar } \\
\text { dengan pixel atau size 1,5 MB }\end{array}$ & $\begin{array}{l}\text { Agar setiap subjek mendapatkan stimulus } \\
\text { visualisasi bahaya merokok yang sama. Serta } \\
\text { gambar tidak pecah/buram. }\end{array}$ \\
\hline & & $\begin{array}{l}\text { Peneliti memilih gambar } \\
\text { dengan saturation (ketajaman/ } \\
\text { fokus) sebesar } 100 \%\end{array}$ & $\begin{array}{l}\text { Agar setiap subjek mendapatkan stimulus } \\
\text { visualisasi bahaya merokok yang sama. Serta } \\
\text { tulisan gambar terlihat jelas. }\end{array}$ \\
\hline & & $\begin{array}{l}\text { Peneliti memilih font pada } \\
\text { tulisan peringatan bahaya } \\
\text { merokok dengan ukuran } 20 \\
\text { dengan jenis tulisan Arial. } \\
\end{array}$ & $\begin{array}{l}\text { Agar setiap subjek mendapatkan stimulus } \\
\text { visualisasi bahaya merokok yang sama. Serta } \\
\text { tulisan yang terlihat jelas. }\end{array}$ \\
\hline \multirow[t]{3}{*}{ RUANG } & Cahaya & \begin{tabular}{|l} 
Peneliti memilih ruangan \\
dengan penerangan lampu 15 \\
Watt
\end{tabular} & $\begin{array}{l}\text { Agar faktor cahaya yang dapat mempengaruhi } \\
\text { tingkat atensi terkontrol. }\end{array}$ \\
\hline & Suhu & $\begin{array}{l}\text { Peneliti memilih rungan yang } \\
\text { memiliki AC dengan suhu } 25 \\
\text { derajat celsius. }\end{array}$ & $\begin{array}{l}\text { Agar faktor suhu yang dapat mempengaruhi } \\
\text { tingkat atensi terkontrol. }\end{array}$ \\
\hline & $\begin{array}{l}\text { Tingkat } \\
\text { kebisingan }\end{array}$ & \begin{tabular}{|l|} 
Peneliti memilih ruangan \\
laboratorium psikologi karena \\
dapat terkontrol dari kebisingan \\
\end{tabular} & $\begin{array}{l}\text { Agar faktor tingkat kebisingan yang dapat } \\
\text { mempengaruhi tingkat atensi terkontrol. }\end{array}$ \\
\hline WAKTU & $\begin{array}{l}\text { Waktu } \\
\text { penglihatan } \\
\text { gambar dan } \\
\text { pengisian } \\
\text { angket }\end{array}$ & \begin{tabular}{l|} 
Peneliti memberikan waktu \\
60 detik atau 1 menit kepada \\
subjek untuk melihat visualisasi \\
bahaya merokok kemudian \\
subjek mengisi angket.
\end{tabular} & $\begin{array}{l}\text { Agar setiap subjek mempunyai waktu yang } \\
\text { sama untuk melihat stimulus visualisasi bahaya } \\
\text { merokok. }\end{array}$ \\
\hline
\end{tabular}

Tabel 3

\section{Uncontrolled Variables}

\begin{tabular}{|l|l|}
\hline \multicolumn{1}{|c|}{ Apa } & \multicolumn{1}{c|}{ Mengapa } \\
\hline Perhatian & $\begin{array}{l}\text { Individu memerlukan sejumlah energi yang dikeluarkan untuk memperhatikan atau } \\
\text { memfokuskan pada bentuk fisik dan fasilitas mental yang ada pada suatu obyek. } \\
\text { Energi tiap orang berbeda-beda sehingga perhatian seseorang terhadap obyek juga } \\
\text { berbeda dan hal ini akan mempengaruhi persepsi terhadap suatu obyek. }\end{array}$ \\
\hline Kebutuhan yang searah & $\begin{array}{l}\text { Faktor ini dapat dilihat dari bagaimana kuatnya seseorang individu mencari obyek } \\
\text { yang dapat memberikan jawaban sesuai dengan dirinya }\end{array}$ \\
\hline Faktor sosial budaya & $\begin{array}{l}\text { Lingkungan sosial dan nilai budaya yang dianut mengenai perilaku merokok berbeda- } \\
\text { beda pada setiap individu sehingga dapat mempengaruhi penilaian individu terhadap } \\
\text { gambar. }\end{array}$ \\
\hline
\end{tabular}

Tabel 4 Hasil Uji Normalitas

\begin{tabular}{|c|c|c|c|c|c|c|c|c|c|}
\hline & & 1 & 2 & 3 & 4 & 5 & 6 & 7 & 8 \\
\hline \multicolumn{2}{|l|}{$\mathrm{N}$} & 7 & 7 & 7 & 7 & 7 & 7 & 7 & 7 \\
\hline \multirow{2}{*}{$\begin{array}{l}\text { Normal } \\
\text { Parametersa,,b }\end{array}$} & Mean & 5.2000 & 4.7629 & 5.4800 & 5.8943 & 3.8286 & 5.3557 & 4.9829 & 5.2629 \\
\hline & $\begin{array}{l}\text { Std. } \\
\text { Deviation }\end{array}$ & 2.13645 & 1.31319 & 1.57594 & 2.16092 & 1.73527 & 2.76282 & 2.66776 & 1.89841 \\
\hline \multirow{3}{*}{$\begin{array}{l}\text { Most Extreme } \\
\text { Differences }\end{array}$} & Absolute & .191 & .241 & .214 & .296 & .190 & .232 & .232 & .228 \\
\hline & \begin{tabular}{|l|} 
Positive \\
\end{tabular} & .184 & .210 & .140 & .154 & .125 & .121 & .120 & .228 \\
\hline & Negative & -.191 & -.241 & -.214 & -.296 & -.190 & -.232 & -.232 & -.142 \\
\hline \multicolumn{2}{|c|}{ Kolmogorov-Smirnov Z } & .505 & .638 & .567 & .782 & .502 & .614 & .613 & .602 \\
\hline \multicolumn{2}{|c|}{ Asymp. Sig. (2-tailed) } & .961 & .810 & .905 & .573 & .963 & .845 & .846 & .862 \\
\hline
\end{tabular}

Tabel di atas tersebut adalah hasil penelitian yang telah dilakukan untuk mengetahui pengaruh pemberian gambar peringatan bahaya rokok terhadap berhenti merokok. Sebelum dilakukan pengujian hipotesis dilakukan uji normalitas dan homogenitas. (Sugiarto, 2006: 49) Uji normalitas dilakukan dengan hipotesis $\mathrm{H}_{0}$ : 
Data berdistribusi Normal dan $\mathrm{H}_{1}$ : Data tidak berdistribusi Normal. Dengan hasil seluruh data treatment $1-8$ berdistribusi normal. $\mathrm{Hal}$ ini dapat dilihat dari nilai p-value (asymp. Sig. 2 tailed) dari tiap treatment yang lebih besar dari nilai $a=0,05$. Uji menggunakan One-Sample Kolmogorov-Smirnov Test.

Uji homogenitas dilakukan dengan hipotesis $\mathrm{H}_{0}$ :Data berdistribusi homogen dan $\mathrm{H}_{1}$ : Data tidak berdistribusi homogen. Berdasarkan uji Levene, dapat disimpulkan bahwa data penelitian memiliki varians yang homogen. Hal ini terlihat dari nilai $F$ sebesar 0,168 dengan nilai $p$ value (sig.) $=0,689>$ $a=0,05$.

Tabel 5 Hasil Uji Homogenitas

\begin{tabular}{|l|c|c|c|c|c|}
\hline & \multicolumn{4}{|c|}{$\begin{array}{l}\text { Levene's Test for Equality } \\
\text { of Variances }\end{array}$} \\
\hline & F & Sig. & T & Df & $\begin{array}{c}\text { Sig. } \\
\text { (2-tailed) }\end{array}$ \\
\hline $\begin{array}{l}\text { Equal } \\
\text { variances } \\
\text { assumed }\end{array}$ & .168 & .689 & -.410 & 12 & .689 \\
\hline $\begin{array}{l}\text { Equal } \\
\text { variances } \\
\text { not } \\
\text { assumed }\end{array}$ & & & -.410 & 10.975 & .690 \\
\hline
\end{tabular}

Untuk mengetahui pengaruh pemberian gambar peringatan bahaya rokok terhadap intensi berhenti merokok dilakukan uji hipotesis $\mathrm{H}_{0}$ : Tidak terdapat perbedaan antara rata-rata pada treatment $\mathrm{A}$ dan rata-rata pada treatment $\mathrm{B}$. $\mathrm{H}_{1}$ : Terdapat perbedaan antara rata-rata pada treatment $\mathrm{A}$ dan ratarata pada treatment $\mathrm{B}$. Pengujian hipotesis dilakukan menggunakan uji $\mathrm{t}$ (t-test) dengan nilai $a=0,05$.

Kelompok 1 adalah uji antara faktor A1B1 vs A2B1, Kelompok 2 adalah uji antara faktor A1B1 vs A1B2, Kelompok 3 adalah uji antara faktor A1B1 vs A2B2, Kelompok 4 adalah uji antara faktor A2B1 vs A1B2, Kelompok 5 adalah uji antara faktor A2B1 vs A2B2, Kelompok 6 adalah uji antara faktor $A 1 B 2$ vs A2B2. Berikut ini hasil uji hipotesis tiap kelompok pada Tabel 6.

Berdasarkan hasil uji t pada tabel 6 diperoleh nilai t sebesar $-0,159$ dengan nilai $p$ value (sig. 2-tailed) sebesar 0,157>a=0,05. $\mathrm{Hal}$ ini berarti terima $\mathrm{H}_{0}$ dan tolak $\mathrm{H}_{1}$. Dengan kata lain, tidak terdapat perbedaan yang signifikan antara rata-rata pada treatment 4 dan rata-rata pada treatment 6 .

Berdasarkan hasil uji t pada tabel 6 , maka uji hipotesis kelompok 1, 2, 3 dan 6 memperoleh hasil nilai $p$ value (sig. 2-tailed) yang lebih besar dari nilai $a=0,05$. Hal ini berarti terima $\mathrm{H}_{0}$ dan tolak $\mathrm{H}_{1}$. Dengan kata lain, tidak terdapat perbedaan yang signifikan antara antar treatment sehingga dapat dinilai bahwa tidak ada pengaruh dari pemberian peringatan bahaya rokok terhadap intensi berhenti merokok.

Namun pada uji hipotesis di kelompok 4 dan 5 terdapat hasil yang berbeda, yaitu hasil nilai $p$ value (sig. 2-tailed) yang lebih besar dari nilai $a=0,05$. Hal ini berarti tolak $\mathrm{H}_{0}$ dan terima $\mathrm{H}_{1}$. Dengan kata lain, terdapat perbedaan yang signifikan antara antar treatment sehingga dapat dinilai bahwa ada pengaruh dari pemberian peringatan bahaya rokok terhadap intensi berhenti merokok.

Apabila dibandingkan dari faktor di dalam kelompok 4 maka diperoleh nilai ratarata A2B1 lebih besar dari A1B2, oleh karena itu dapat disimpulkan bahwa A2B1 lebih berpengaruh pada intensi berhenti merokok. Pada faktor di dalam kelompok 3 maka diperoleh nilai rata-rata A2B1 lebih besar dari A2B2, oleh karena itu dapat disimpulkan bahwa A2B1 lebih berpengaruh pada intensi berhenti merokok.

Oleh karena itu, bila dilihat dari perbandingan nilai rata-rata maka memiliki kesamaan yaitu faktor A2B1 yang lebih berpengaruh. A2B1 memiliki nilai yang jauh lebih tinggi dibandingkan nilai faktor. Hal ini yang membuat uji hipotesis menunjukkan hasil perbedaan yang signifikan. Oleh karenanya, A2B1 berpengaruh pada intensi berhenti merokok subjek penelitian.

Tabel 6

Hasil Uji Hipotesis (t-test)

\begin{tabular}{|c|c|c|c|c|c|c|}
\hline Kelompok & $\mathbf{1}$ & $\mathbf{2}$ & $\mathbf{3}$ & $\mathbf{4}$ & $\mathbf{5}$ & $\mathbf{6}$ \\
\hline Nilai $\mathrm{t}$ & 0,505 & $-0,410$ & $-0,486$ & $-1,238$ & $-2,653$ & 1,685 \\
\hline p-value $(\mathrm{sig})$ & 0,623 & 0,393 & 0,357 & 0,023 & 0,021 & 0,118 \\
\hline Hasil & $\mathrm{t}>\mathrm{a}$ & $\mathrm{t}>\mathrm{a}$ & $\mathrm{t}<\mathrm{a}$ & $\mathrm{t}<\mathrm{a}$ & $\mathrm{t}<\mathrm{a}$ & $\mathrm{t}>\mathrm{a}$ \\
\hline Hipotesis & $\begin{array}{c}\mathrm{H}_{0} \\
\text { diterima }\end{array}$ & $\begin{array}{c}\mathrm{H}_{0} \\
\text { diterima }\end{array}$ & $\begin{array}{c}\mathrm{H}_{0} \\
\text { diterima }\end{array}$ & $\begin{array}{c}\mathrm{H} 0 \\
\text { ditolak }\end{array}$ & $\begin{array}{c}\mathrm{H} 0 \\
\text { ditolak }\end{array}$ & $\begin{array}{c}\mathrm{H}_{0} \\
\text { diterima }\end{array}$ \\
\hline
\end{tabular}


Pada dasarnya pembangunan generasi muda merupakan pembangunan insan manusia yang mempertimbangkan manusia tidak hanya sebagai alat, namun sebagai akhir tujuan proses pembangunan. Seluruh upaya dalam pembangunan diarahkan kepada orang dan kesejahteraannya dan generasi muda diperlakukan sebagai pelaku pembangunan ekonomi suatu bangsa. (Sengupta dalam Sundaya, 2006: 521). Oleh karena itu, pembentukan generasi muda dengan karakter yang kuat menjadi faktor yang penting untuk tercipta pembangunan bangsa yang optimal.

Dilihat dari bahaya rokok dalam masalah kesehatan, maka rokok menjadi hal yang sangat berdampak negatif bagi kesehatan tubuh yang dapat mempengaruhi pembangunan generasi dan bangsa. (Hamdan, 2013) Dampak rokok secara umum berbahaya bila dikonsumsi dalam jangka panjang oleh generasi muda bangsa Indonesia. Untuk lebih jelasnya, berikut ini bahaya rokok bagi kesehatan tubuh bila dikonsumsi secara jangka panjang, diantaranya: Kematian, Penyakit jantung, Berbagai jenis kanker mematikan, Gangguan Reproduksi, Impotensi dan Gangguan Ereksi, Gangguan Pernafasan Kronis, Stroke, Tukak lambung, Penyakit burger, Pengkroposan tulang atau yang dikenal dengan osteoporosis, Penuaan dini, Rambut rontok, Perusakan organ pendengaran, Merusak gigi, Kerusakan organ mata (Sarafino, 2002 : 146, bahayamerokok. net dan Wikipedia.org/Rokok)

Dari bahaya-bahaya kesehatan tersebut, kini pemerintah memberikan penekanan bahaya rokok dalam bentuk lima gambar yaitu adalah kanker mulut, kanker paru-paru dan bronkitis akut, kanker tenggorokan, merokok membahayakan anak (ilustrasi bapak menggendong anak sambil merokok).

Namun menjadi catatan bahwa dari lima gambar yang diterapkan, hanya tiga gambar yang secara jelas dan eksplisit menunjukkan bahaya kesehatan yaitu gambar kanker mulut, kanker paru-paru \& bronchitis dan kanker tenggorokan. Pemberian gambar dan peringatan tentang dampak dari rokok berdampak positif di Australia. Pemerintah Australia sudah memberlakukan penggunaan bungkus yang baru pada kemasan rokok dan menimbulkan berbagai dampak pada perokok seperti merasa tidak enak saat merokok saat melihat kemasan rokoknya (www. poskotanews.com).

Gambar peringatan pada bungkus rokok di Indonesia dirasa masih terlalu kecil ukurannya. Sehingga gambar peringatan tersebut belum benar-benar menjadi peringatan. Masih seperti halnya pajangan belaka. Gambar peringatan bahaya merokok (picture warning) dalam Peraturan Pemerintah (RPP) tentang Pengamanan Produk Tembakau cuma sebesar $40 \%$ dari bungkus rokok. "Pemerintah Indonesia kurang peduli kesehatan rakyatnya." Prijo Sidipratomo yang diamini Ketua Komisi Nasional Perlindungan Anak (Komnas PA) menyatakan di negara tetangga seperti Thailand, Singapura, dan Australia gambar bahaya rokok pada bungkus rokok mencapai $70 \%$ sampai $90 \%$. (Aby dalam www.poskotanews.com)

Diberikannya gambar peringatan bahaya rokok pada bungkus rokok diharapkan dapat membuat perokok jera dan akhirnya memutuskan untuk berhenti merokok. Jika tidak pun setidaknya pemerintah sudah dapat mensosialisasikan bahaya rokok yang tepat dan akurat. Ketua Tobacco Control Support Center-Ikatan Ahli Kesehatan Masyarakat Indonesia, dr Kartono Mohamad mengatakan bahwa tujuan PP 109 adalah perokok pemula. Ia mengatakan bahwa bagi perokok pemula diharapkan akan takut untuk meneruskan merokok dan berusaha berhenti jika sudah tahu akibatnya. (Wijaya dalam kompas.com)

Bila dilihat dari hasil penelitian, dapat dilihat bahwa penggunaan treatment gambar dengan tulisan tidak semua menghasilkan data yang signifikan. Namun pemberian peringatan bahaya rokok bergambar penyakit dengan tulisan baru memiliki pengaruh terhadap intensi berhenti merokok. Berdasarkan data deskripsi yang diperoleh melalui wawancara pada subjek penelitian, diperoleh pula bahwa gambar penyakit kanker mulut berpengaruh pada penilaian yang lebih berpengaruh mengenai bahaya rokok. Tulisan yang lebih pendek juga dihayati subjek menunjukkan bahaya yang lebih pasti.

Kebanyakan orang Indonesia malas membaca. Menurut Data Badan Pusat Statistik tahun 2006, penduduk Indonesia yang menjadikan baca sebagai sumber informasi baru sekitar $23,5 \%$, sedangkan yang menonton televisi $85,9 \%$ dan mendengarkan radio $40,3 \%$. (kompas.com) Sehingga pada dasarnya tulisan yang lebih singkat dan jelas akan menarik perhatian dan lebih dibaca dibandingkan tulisan yang panjang dan sarat informasi. Tulisan peringatan bahaya merokok umumnya dicantumkan di iklan dan banner, dan orang umumnya hanya melewatkan 1-2 detik saja untuk membacanya. 
Tulisan juga harus bersifat bersifat persuasif dan dramatis maksudnya tulisan harus dapat memanfaatkan ungkapanungkapan yang hidup dan kontras-kontras yang mencolok. Tulisan dapat menggugah pembacanya untuk menilai dan menentukan tindakan.

Dalam peringatan bahaya rokok bergambar, meskipun telah disurvei sebelumnya oleh Kementerian Kesehatan, namun ternyata tidak semua gambar bahaya rokok berpengaruh terhadap intensi berhenti merokok. Gambar bahaya dengan gambar orang merokok dan asap rokok yang jelas terlihat, terbukti tidak memberikan pengaruh signifikan. Dari hasil wawancara, subjek penelitian menyatakan bahwa gambar orang merokok dan asap merokok bahkan mengingatkan mereka untuk merokok dan pesan bahaya rokok tidak mereka hayati. Pengetahuan bahaya rokok saja tidak membuat mereka berhenti merokok. (Harnowo dalam detik.com)

Gambar penyakit lebih dihayati memperingatkan mengenai bahaya rokok dan memberikan kesan takut sehingga cukup mendorong mereka untuk meningkatkan intensi untuk berhenti merokok. Gambar penyakit kanker mulut disepakati oleh seluruh subjek penelitian sebagai gambar yang paling menakutkan dan secara signifikan membuat mereka ingin berhenti merokok. Alasan mengapa gambar penyakit kanker mulut lebih meningkatkan intensi berhenti merokok karena gambar lebih jelas menggambarkan resiko penyakit dari merokok. 24 subjek menyatakan gambar tersebut menjijikkan, 39 subjek menyatakan menakutkan dan semua subjek menyatakan gambar tersebut lebih jelas bahayanya.

\section{Simpulan dan Saran}

Berdasarkan hasil eksperimen diatas maka dapat disimpulkan bahwa tulisan "MEROKOK MEMBUNUHMU" lebih berpengaruh dibandingkan tulisan lama. Gambar penyakit dengan gambar kanker mulut lebih berpengaruh dibandingkan gambar peringatan yang lain. Kombinasi gambar kanker mulut disertai tulisan baru yang lebih singkat dinilai lebih efektif dalam mempengaruhi secara signifikan pada intensi berhenti merokok.

Oleh karena itu, disarankan bagi pemerintah khususnya Departemen Kesehatan untuk mengevaluasi penerapan peringatan bahaya rokok dengan mempertimbangkan hasil penelitian ini. Peringatan dengan kombinasi gambar kanker mulut disertai tulisan baru yang lebih singkat terbukti lebih efektif dalam mempengaruhi perokok agar berhenti merokok.

\section{Ucapan terima kasih}

Penulis ucapkan terima kasih banyak kepada Hanifa Nur Lathifah, Linda Purnamawati, R. Annissa Kheista A., Rizka Eka Ananda Putri, Johan Prasetyo dan Rani Chintiawati yang telah melaksanakan studi eksperimen pendahuluan dari hasil penelitian ini.

\section{Daftar Pustaka}

Aby (2012). Gambar Peringatan Bahaya Rokok di Indonesia Terlalu Kecil. (http:// poskotanews.com/2012/09/23/gambarperingatan-baahaya-merokok-indonesiaterlalu-kecil/) di unduh 3 Maret 2014.

Ajzen, Icek.(2005). Attitudes, Personality and Behavior. Open University Press: New York.

Albery, Ian P. \& Munafo, Marcus. (2011). Psikologi Kesehatan, Panduan Lengkap dan Komprehensif Bagi Studi Psikologi Kesehatan. Mitra Setia.

Aula, Lisa Ellizabeth. (2010). Stop Merokok! Sekarang atau Tidak Sama Sekali. Bandung : Garailmu.

Barber, Sarah. 2008. Ekonomi Tembakau di Indonesia. Jakarta : Lembaga Demografi Fakultas Ekonomi Universitas Indonesia.

Candra, Asep. (2012). Perokok Lakilaki di Indonesia Capai 67 Persen. (http://health.kompas.com/ read/2012/09/11/19275290/Perokok. Laki-laki.di.Indonesia.Capai.67.Persen) diunduh 3 Maret 2014.

Efendi, Efendi, Mohammad. (2005). Penggunaan Cognitive Behavior Therapy untuk Mengendalikan Kebiasaan Merokok di Kalangan Siswa melalui Peningkatan Perceived Self Efficacy Berhenti Merokok. Jurnal Pendidikan dan Kebudayaan No. 056, Tahun ke-11, September 2005. (www.isjd.pdii.lipi.go.id) diakses pada 8 November 2011.

Hamdan, Stephani Raihana. (2013). Thesis: Pengukuran dan Intervensi Perilaku Merokok Menggunakan Pendekatan Implisit. Magister Profesi Fakultas Psikologi Universitas Padjadjaran.

Harnowo, Putro Agus. (2012). 86\% orang Indonesia sadar Bahaya Rokok Bagi Kesehatan. (http:// health.detik.com/read/2012/09/11 
/162428/2014983/763/86-persen-orangindonesia-sadar-bahaya-rokok-bagikesehatan?/771108bcj) diunduh 19 September 2012.

Hatta, M. Ilmi (2013). Pengaruh "Group Counselling" terhadap "Self-Regulation" Pecandu Napza pada Jurnalis Televisi X. Jurnal MIMBAR, Sosial dan Pembangunan Vol 29 No 1 (Juni-2013). Hal 57-68.

Kementrian Kesehatan RI. (2012) Anak dan Remaja Rentan Menjadi Perokok Pemula. (http://www.depkes.go.id/ index.php? $v w=2 \& i d=2050)$ diunduh 3 Desember 2013

Mubarak, Ali, Hamdan, Stephani R, Sumarna, Eggy P. (2014). Studi Kontribusi Faktor Determinan Intensi Merokok Dalam rangka pencegahan perilaku merokok pada siswa Sekolah Dasar di Kota Bandung. Bandung : Prosiding Sosial, Ekonomi, dan Humaniora, Vol.4, No.1, Tahun 2014 halaman 36-46.

Nurcahyani, Dwi Indah. (2014). Jumlah Pria Perokok di Indonesia Tertinggi Kedua di Dunia. (http://health.okezone.com/ read/2014/01/09/482/924216/jumlahpria-perokok-di-indonesia-tertinggikedua-di-dunia/large). Diunduh 3 Maret 2014.

PP No.19 Tahun 2003 tentang Pengamanan Rokok Bagi Kesehatan. (http:// bppt.jabarprov.go.id/assets/data/ arsip/019-03.pdf) diunduh 11 November 2013

Redaksi Jawapos. (2014). Gambar Seram di Bungkus Rokok Berlaku. (http://www. jawapos.com/baca/artikel/3259/GambarSeram-di-Bungkus-Rokok-Berlaku) diunduh 18 April 2014.

Rustan, Surianto. (2009). Mendesain Logo. Jakarta: PT Gramedia.

Sarafino, Edward P. (2002). Health Psychology: Biopsychosocial Interaction. John Wiley \& Sons.

Sugiarto. (2006). Metode Statistika. Jakarta: PT. Gramedia Pustaka Utama.
Sulaiman, M. Reza. (2013). Pemerintah: Peringatan Bahaya Rokok Bukan Untuk Perokok. (http://health.detik.com/rea d/2013/12/27/193401/2452817/763/ pemerintah-peringatan-bahaya-merokokbukan-untuk-perokok) diunduh 3 Maret 2014.

Sundaya, Yuhka. (2006). Hambatan Pencapaian Target Daya Beli Sebagai Pembentuk Kualitas Pembangunan Manusia di Jawa Barat. Jurnal MIMBAR Vol. 22 No. 4 Tahun 2006. Halaman 521

Tim Kompas. (2012). Juragan rokok menjadi orang terkaya Indonesia. (http://ekonomi. kompasiana.com/bisnis/2011/11/28/ juragan-rokok-menjadi-orang-terkaya-diindonesia) diunduh 2 Maret 2012

Tim Kompas. (2013). Begini Aturan Iklan Rokok. (http://health.kompas.com/ read/2013/05/31/15332953/Begini. Aturan.Iklan.Rokok) diunduh 11 November 2013

Tim KPAI (2013) Menyelamatkan Anak Dari Bahaya Rokok. (http://www.kpai.go.id/ tinjauan/menyelamatkan-anak-daribahaya-rokok/) diunduh 30 November 2013.

Tim Redaksi Sindotrijaya. (2013). Peraturan Menkes Bagi Kemasan Rokok. (http:// www.sindotrijaya.com/news/detail/3868/ pemerintah-berlakukan-peraturanmenkes-bagi-kemasan-rokok). Diunduh 3 Maret 2014.

Tim Website (2011) Bahaya Merokok Bagi Remaja. (http://bahayamerokok.net/ bahaya-merokok-bagi-pelajar.html) diunduh 3 Maret 2012

Wijaya, L.Sastra. (2012). Rokok Terasa Tidak Enak Setelah Bungkusnya Diganti. (http://entertainment.kompas.com/ read/2012/11/30/09230292/Rokok. Terasa.Tidak. Enak.Setelah.Bungkusnya. Diganti). Diunduh 3 Maret 2014.

Wikipedia. (2015). Rokok. (http://id. wikipedia. org/wiki/Rokok) diunduh 5 Februari 2015. 